\title{
Estimation of the Quality of Tax Administration in the Russian Federation
}

\author{
Nasyrova V. \\ Kazan Federal University, Institute of Management, Economics and Finance, Kazan, 420008, Russia
}

Email: vin75278@gmail.com

\section{Doi:10.5901/mjss.2015.v6n1s3p16}

\section{Abstract}

This article is devoted to approaches to the estimation of the quality of tax administration, the basic criteria for estimation of the quality of tax administration, use in scientific literature and in practice of tax authorities is considered; emphasis made on the influence of factors of entrepreneurship activity in regional aspects of tax administration; possibilities of using of some indicators of the quality of tax administration are summarized; the conclusion is made on the necessity of estimation of the quality of tax administration by direct and indirect indicators.

Keywords: tax administration, quality of tax administration, criteria for estimating the quality of tax administration, collecting of taxes.

\section{Introduction}

In the scientific literature, a subject of a heated discussion for many years remains a question of the effectiveness of implementation of a tax policy. An important aspect of tax policy implementation is tax administration. For a long time the scientific community has developed questions regarding the estimation of the efficiency of tax control, and various approaches, methods and estimation policies were offered. However, tax administration is a higher level concept and tax control is only a part of it. Certainly, the practical implementation of tax administration shows in a higher degree through tax control, but it is only a component of tax administration. In our opinion, the questions of the estimation of the quality of tax administration are not given proper attention.

In the light of recent trends of the economic development of our country and transformations in tax imposition, underestimating the role of the quality of tax administration is impropriate. A generally acknowledged fact is that the forms and methods of implementation of a tax policy are no less important than arrangements and reforms. Foreign experience has demonstrated to us that effective tax administration secures the health of the taxation system [1], [2].

The efficiency of the activity of state structures can be defined by the ratio of results and costs [3]. The question lies in how much this efficiency depends on efforts of government authorities and how it is determined by the characteristics of managing a system itself. In our case the quality of tax administration and the level of development of the taxation system are interdependent and interacting factors. The difficulties of estimation of the quality of tax administration lie in the impossibility of authentically estimating a share of this or that parameter of the taxation system which is directly associated with tax administration. The selection and the estimation of these parameters are conditional enough, however, the necessity of its monitoring is undisputed.

\section{Method}

Tax administration is commonly understood as the managing of tax relations by government authorities, which are allotted with credentials and duties in the field of taxing and tax imposition in order to assure realization of a tax policy and following the tax legislation.

Russian tax policy at the present stage includes a number of arrangements, the realization of which is closely connected with tax administration. These include an accretion of tax collection, control of offshore accounts, improvement of control in transfer price formation, a development of interconciliatory procedures in tax relations, counteraction of tax evasion.

It is difficult to estimate the quality of these characteristics and to discuss their dynamics. However, it is necessary to separate the number of indicative factors, the analysis of the dynamics of which will enable us to discuss the tendencies in tax administration [4].

Certainly, for a long time the indicator of tax collection was the basic indicator for characterizing the tax administration. It was widely used by both the theorists and experts of taxation. The collecting of taxes in a general sense 
was understood as a ratio between the size of actually collected taxes and tax rates, which should be collected according to size of the taxable base and the tax rates provided by the tax legislation of the country [5].

$\mathrm{C}=\mathrm{TR} / \mathrm{TC} * 100 \%$, where

C - collection,

TR - real tax revenues,

TC - tax charges

Recently, it was realized that collection factor not only defines the quality of tax administration, but also the efficiency of the taxation system as a whole. The factor was essentially different among different taxes; moreover, tax collection from individuals [assessed tax] was higher than from legal entities.

The primary stumbling block in the estimation of the quality of tax administration is the fiscal efficiency of particular taxes. From 2015 the imposition of a sales tax with the maximum rate of $3 \%$ had been planned. Heated discussion was held regarding the suitability of such arrangements. Increasing the rate by $2 \%$ was considered as an alternative variant. The main argument of rate increase supporters was the low collection of sales tax in 1990-91 and in 1998-99, which was about $30 \%$.

According to the Minister of Finance of the Russian Federation, in modern conditions the collecting of the sales tax would be significantly higher, by the reason of widely developed regional trade networks and the improvement of the quality of tax administration. At the same time, the Ministry of Finance acknowledged all the complexity of tax administration of the sales tax and the increased load on taxing authorities.

The government deliberately planned imposing the tax with the potentially low collection rate and using the collection index for estimating the quality of administration of the sales tax is inadmissible. In this case the tax with low economic effectiveness (as evidenced by two unsuccessful attempts in 1991 and 1998) will bring to nothing all the attempts of taxing and financial authorities for the creation of effective tax administration. However, this doesn't signify the impossibility of the estimation of the quality of the sales tax administration.

In this case at least it is incorrect to characterize tax administration of the sales tax by the indicator of collection. The example of the sales tax makes visible how difficult it is to estimate the quality of tax administration as a whole and taxes in particular.

Here we approach an utterly important factor of tax administration: the fiscal efficiency of taxes. The literature allocates taxes with low, high, and neutral fiscal efficiency [6]. The value-added tax is considered to be an example of a tax with high fiscal effectiveness. With the proper organization of tax administration this tax provides a $100 \%$ collection rate. Moreover, the period and procedure of its payment may be formed for specific economic conditions, as was done in 2009.

Among the taxes with low fiscal effectiveness are taxes that can be easily evaded and whose level of evasion is sufficiently high. As an example, the sales tax entered into the tax system of the Russian Federation twice and twice showed its low fiscal effectiveness. This was primarily due to the volumes of shadow turnover in retail trade [7], [8].

\section{Result}

Addressing the statistical data of the Federal Tax Agency of the Russian Federation, it is possible to draw the following conclusions.

The level of tax revenues tended towards growth [9],[10].

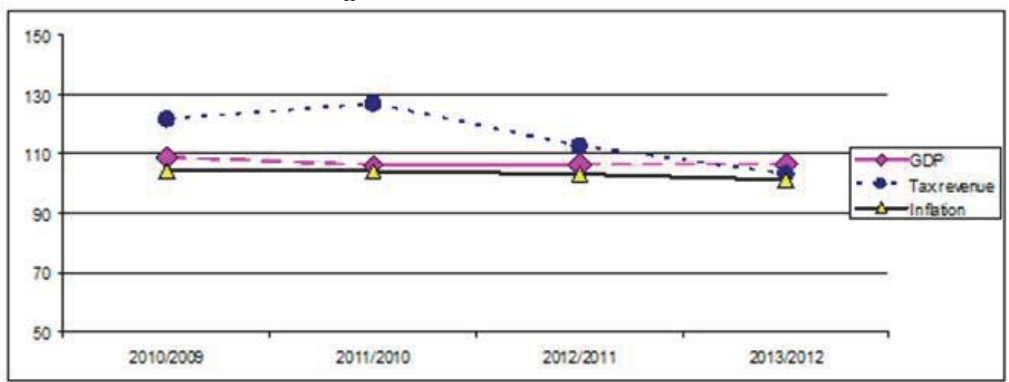

Fig. 1. Growth rates of tax revenues, Gross domestic product and inflation, in $\%$

According to the pictured information it is conspicuous that the growth rates of tax revenues are decreasing, however, according to all available information the situation in 2014 is much more successful in comparison with the similar period of 2013. To the number of main causes of significant growth of a rate decrease it is necessary to include the common 
economic situation and a temporary lag effect, typical for tax payments. Generally, a slowdown in economic growth doesn't coincide with a slowdown in tax revenues. This is due to the mechanism of calculation and tax payments, and to the procedures of tax administration.

Against a decrease in gross domestic product growth and an increased rate of inflation, the rate of increase of tax revenues is more than considerable. According to the tax service of the Russian Federation, in the nine months of 2014, tax revenue growth outstripped the inflation level, and the quality of tax administration played the significant role in it.

The collecting of taxes throughout the last five years (2009-2013) as a whole across Russia is observed at level above 100\%. Let's consider this indicator in more detail in a cut of the federal, regional, and local taxes and the taxes levied within the limits of special tax regimes.

Table 1: Collecting of taxes in the Russian Federation for 2009-2013gg., \%

\begin{tabular}{|l|c|c|c|c|c|}
\hline Indicator & 2009 & 2010 & 2011 & 2012 & 2013 \\
\hline Collecting, as a whole on the taxation system & 130,32 & 126,15 & 127,07 & 122,95 & 127,45 \\
\hline On the federal taxes & 134,52 & 130,72 & 128,84 & 126,19 & 131,71 \\
\hline On regional taxes & 95,94 & 96,05 & 99,75 & 95,65 & 98,28 \\
\hline On the local taxes & 99,74 & 96,78 & 275,34 & 94,32 & 100,17 \\
\hline On taxes within the limits of special tax regimes & 153,46 & 104,57 & 110,11 & 113,07 & 107,12 \\
\hline
\end{tabular}

According to the table, federal taxes have the highest tax collection rate. An exception to this rule was the collection of local taxes in 2011 which was due to the change of payment dates and the change of an order of administration of the assessed taxes from individuals. The number of federal taxes also includes the value-added tax, excises, the profits tax, the income tax from individuals, the mineral extraction tax, the state tax, and a number of others. A special value among the federal taxes is derived from the taxation of oil extracting [11]. Among the regional and local taxes, indirect taxes are absent. The situation of the economy for the last five years did not allow us to suggest the lack of influence of the tax level load on the indicators of collection.

Typical for the Russian taxation system is the concentration of taxes with high fiscal effectiveness on the federal level. Imposing a sales tax, according to legislators, should have corrected this misbalance, because the sales tax was planned as regional. Discussion about the expediency of parallel usage of the added value tax and the sales tax became the subject of separate scientific research. In the study of the quality of tax administration, an important step is revealing a dependence on the effectiveness of a particular tax [12].

I would like to touch on the taxes levied under special tax regimes. The indicator of their collection is erratic from year to year. However, the administrative costs on a tax control of the subjects, which applies to special tax regimes, are significantly high. . This is evidenced by a specific weight of tax income and pre-charges via the results of tax inspection of one tax payer [13].

Another indicator of estimation of the quality of tax administration used by federal tax revenue of RF is the ratio of back taxes to tax revenues [14].

Table 2: Ratio of back taxes, possible to collect, to tax revenues in the Russian Federation for 2009-2013gg., \%

\begin{tabular}{|l|c|c|c|c|c|}
\hline Indicator & 2009 & 2010 & 2011 & 2012 & 2013 \\
\hline Ratio of back taxes to tax revenues & 10,97 & 9,04 & 6,73 & 6,59 & 6,76 \\
\hline On the federal taxes & 10,54 & 8,44 & 6,30 & 5,95 & 6,01 \\
\hline On the regional taxes & 13,46 & 13,85 & 13,84 & 13,21 & 13,24 \\
\hline On the local taxes & 27,31 & 24,70 & 20,39 & 20,20 & 21,68 \\
\hline On taxes under special tax regimes & 8,05 & 7,68 & 6,95 & 6,83 & 7,27 \\
\hline
\end{tabular}

According to the table the positive tendency is stable enough. And if an indicator of the taxes under special regimes is the lowest, an indicator of the local taxes is the highest.

Several researches of tax administration work effectiveness revealed interesting regularities. Regions with a similar economic situation have shown sharp distinctions in the results of examination of taxing authorities. Therefore, we can suggest opportunities of organization of a high-quality tax administration at the level of federal subjects of the Russian Federation. In other words, despite rigid centralization and a strict regulation of activity of tax authorities, results of an examination of regions could vary considerably. This can be used as the methodology for estimation of the quality of tax administration. The approach could be based on ranking the regions in terms of economic development and tax burden, and an estimation of the effectiveness of tax control within the groups with the same level of social and economic indexes 
and regional tax burden.

Certainly, we cannot ignore the level of entrepreneurial activity of regions, since the interaction of a tax system and an entrepreneurial environment is represented by the interdependent changes of their characteristics. The quality of tax administration depended on the structure of taxpayers in the region and on the proper organization of work with them. Tax inspections of the largest taxpayers proved most effective; however, not in all regions as in some it meant a concentration of efforts of taxing authorities only on this category of taxpayers. Again, a sharp dissent occurs in the coverage of small businesses in regions by high-quality tax administration.

\section{Conclusion}

Despite all the complexity of estimation of the quality of tax administration, it is necessary to allocate a number of indicators which directly or indirectly define different aspects of tax administration. A number of direct indicators include growth rates of tax revenues, collection of tax payment, pre-charges as a result of tax inspections, structure dynamics of tax payers, indicators of tax revenues of one tax payer, etc.

A number of indirect indicators include indicators based on estimates of experts, for example the integrated indicator, "doing business", of The World Bank. Within this indicator the tax burden condition is assessed. The "doing business" study analyzes taxes and required tax deductions that medium businesses should pay in a given year, as well as the administrative burden due to tax payment and production of deductions. Among the number of considered taxes and allocations are income tax or corporate tax, social security allocations and labor taxes paid by employers, the property tax, the property surrender tax, the dividend tax, tax on capital gains, tax on financial transactions, tax on waste collection, tax on vehicles and road tax, as a well as any other small taxes and fees. Remarkably, the current indicator takes into account not only taxes, but also other fiscal payments (social contributions, environmental fees, etc.) [15].

The values of this indicator in the Russian Federation in 2013 had constitute - 63 and in 2014 - 56. Remoteness from the forward boundary had to constitute in $2013-73.39$, and in $2014-75.33$ percentage points.

Thus, an estimate of the quality of considered tax administration indications solves particular problems, however, they don't define the whole picture. For the purposes of microanalysis it is possible to use the aggregate of direct (tax revenue collection growth rate, collection, the ratio of dept to tax revenue) and indirect (the "doing business" integrated indicator) criteria, however the sharp dissention in regional tax administration quality demands further studies.

\section{References}

Baccini L., Li Q., Mirkina I. Corporate Tax cuts and foreign direct investment // Journal of policy Analysis and Management, 2014, № 33(4), pp.977-1006.

Bach S. Corneo G., Steiner V. Effective Taxation of top incomes in Germany // Garman Economic Review, 2013, № 14 (2). pp. 115-137.

Demyanova, O.V., Valitov M.S. A Multidimensional assessment of the efficiency of the Russian economy // World Applied Sciences Journal, 2013, Volume 25, Issue 5: pp. 760-767.

Musaeva K. The increase of tax administration effectiveness, as a factor of shadow sector validation and growth of economic security // Life Science Journal, 2014, № 11(7), 46 pp. 229-233.

Musaeva K. Institutional aspects of tax planning in the conditions of reforming of tax system and improvement of tax management // World Applied Sciences Journal, 2013, Volume 27, Issue 5, pp. 643-648.

Orlova M., Khafizova A. The tax component of innovative activity assessment in the Russian Federation // Life Science Journal, 2014, № 11(11), pp. 328-333.

Selivanovskaya J.I., Talan M.V. Responsibility for legalization of proceeds from crime in international statutory instruments and legislation of the Russian Federation // Life Science Journal, 2014, № 11(8), pp. 150-154.

Jost S.P. Pfaffermayer M., Winner H. Transfer pricing as a tax compliance risk // Accounting and Business Research, 2014, № 44(3). pp. $260-279$.

Official website of Federal State Statistics Service [online]: Technical innovation cost structure of industrial production and sources of its formation.- Available at: <http://www.gks.ru/free_doc/new_site/business/nauka/ind_2020/pril3.pdf>

Official website of Federal Tax Service of the Russian Federation [online]: Summary reports for the Russian Federation in a whole and for subjects of the Russian Federation.- Available at: http://nalog.ru/rn63/related_activities/statistics_and_analytics/

Valitov Sh.M., Tufetulov A.M., Jartiev A.F. Effect of crud quality on crud oil refining efficiency // Neftyanoe Khozyastvo - Oil Industry, 2012, № 12, pp. 132-135.

Aliyev B.K., Musaeva K.M., Magomedtagirov M.M. Development of tax Federalism - the basis for formation of self-developing territorial systems in the Russian Federation // Life Science Journal, 2014, № 11(8), 10 pp. 57-61.

Orlova V. Development of Small business: modern realities and new directions of public policy // Economic Annals XXI, 2013, Volume 5-6, Issue 1, pp. 18-21.

IOTA working group positively evaluate the work of Federal Tax Service of Russian Federation on dept reduction. http://nalog.ru/rn63/news/seminar/4963755/

Bachini L. Corporate taxes and direct foreign investments // Journal of policy Analysis and Management, 2014, Volume 33, Issue 4, pp. $977-1006$. 